\title{
KONTESTASI KOMODIFIKASI MEDIA MASSA DAN IDEOLOGI MUHAMMADIYAH
}

\author{
Mariana Ulfah \\ Program Studi Ilmu Komunikasi Universitas Ahmad Dahlan, Jl. Pramuka 42, \\ Sidikan, Umbulharjo, Yogyakarta 55161, Telp. (0274) 669188, E-mail: \\ mj.mariajova@gmail.com
}

\begin{abstract}
This study aims to determine the contestation commodification and mass media Muhammadiyah ideology. Television media industry is a capital intensive industry types. This compares with the strength to build a perception in society, resulting in the attraction of various interests disana.Pada generally a television station is affected by the strength of the owner, the advertising, and rating. One local TV station, ADiTV, has the additional element that also affects the identity tayangannya Muhammadiyah, as its founder. In this study, using a qualitative descriptive. Through descriptive method will be able to explain the phenomenon in detail and presents a more detailed analysis that can not afford revealed by quantitative methods. The identity of a television media is very important to determine the standard of impressions and development of the company in the long term. Ambiguity status Muhammadiyah TV ADiTV whether or not can be detrimental for both parties ADiTV either alone or Muhammadiyah. ADiTV losses include the whole range ADiTV can not freely determine the policy, especially pertaining to the propaganda value of Muhammadiyah
\end{abstract}

Keyword: ADiTV, TV show, local TV, commodification, ideology, Muhammadiyah.

\begin{abstract}
Abstrak
Penelitian ini bertujuan untuk mengetahui kontestasi komodifikasi media massa dan ideologi Muhammadiyah. Industri media televisi merupakan jenis industri padat modal. Ini sebanding dengan kekuatannya untuk membangun persepsi di masyakarat, sehingga terjadi tarikmenarik berbagai kepentingan disana.Pada umumnya sebuah stasiun televisi dipengaruhi oleh kekuatan pemilik, kebutuhan iklan, dan rating. Salah satu Stasiun TV lokal, ADiTV, memiliki unsur tambahan yang juga mempengaruhi tayangannya yakni identitas Muhammadiyah, sebagai pendirinya. Dalam penelitian ini menggunakan deskriptif kualitatif. Melalui metode diskriptif akan mampu memaparkan fenomena secara rinci serta menghadirkan analisis yang lebih mendalam yang tidak mampu diungkap dengan metode kuantitatif. Identitas sebuah media televisi sangat penting untuk menentukan standar tayangan dan perkembangan perusahaan dalam jangka panjang. Ketidakjelasan status ADiTV apakah TV Muhammadiyah atau bukan dapat merugikan bagi kedua belah pihak baik ADiTV sendiri maupun Muhammadiyah. Kerugian ADiTV diantaranya adalah seluruh jajaran ADiTV tidak dapat bebas menentukan kebijakan terutama yang bersinggungan dengan nilai dakwah Muhammadiyah.
\end{abstract}

Kata kunci : ADiTV, tayangan, televisi lokal, komodifikasi, ideologi, muhammadiyah. 


\section{Pendahuluan}

Industri pertelevisian merupakan industri komersil padat modal dan sarat dengan berbagai kepentingan. Pendapatan utama media televisi adalah melalui iklan. Tiga hal yang mempengaruhi industri ini adalah pemilik (owner), rating, dan iklan seperti yang dijelaskan pada gambar 1 . Idealnya para pelaku bisnis akan memasang iklan pada tayangan program favorit atau yang memiliki rating tinggi dan pemilik memiliki hak dalam setiap keputusan. Tarik-menarik antar tiga hal: pemilik, rating dan iklan, sudah cukup ketat ketika menentukan tayangan sebagai output sebuah TV. Tidak semua tayangan TV yang menjadi favorit pemirsa dinilai baik oleh Komisi Penyiaran Indonesia (KPI) maupun masyarakat dari segi konten tayangan sehingga menimbulkan pro dan kontra. Tidak semua tayangan TV dengan rating tinggi akan luput dari teguran KPI. Begitu juga dengan tayangan dokumentasi kegiatan "si pemilik" yang tidak menjadi favorit pemirsa tapi tetap ditayangkan.

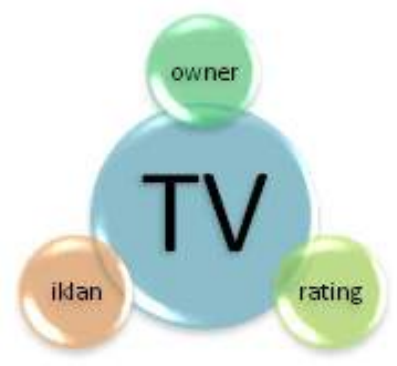

Gambar 1.Tiga (3) hal yang mempengaruhi TV yaitu owner, rating, dan iklan.

ADiTV merupakan salah satu stasiun televisi lokal di Yogyakarta.Televisi ini cukup identik dengan Muhammadiyah selaku pendiri. ADiTV adalah televisi Muhammadiyah pertama yang lahir pada Muktamar se-abad Muhammadiyah, Juli 2010 lalu. Muhammadiyah sebagai salah satu organisasi Islam terbesar di Indonesia tentu tidak akan lepas dari kegiatan dakwah agama Islam. Impian Muhammadiyah untuk go international diawali dengan menjalankan stasiun televisi lokal ini. Harapannya adalah dakwah menjadi lebih efektif, efisien, dan dapat disebarkan lagi secara lebih luas hingga internasional. Sebagai perusahaan TV komersil, ADiTV tidak akan lepas dari kebutuhan komersilnya. Iklan, rating, dan keinginan pemilik akan mempengaruhi tayangan yang ada. Namun di sisi lain, visi misi gerakan dakwah Muhammadiyah juga menjadi pertimbangan lain seperti terlihat pada gambar 2:

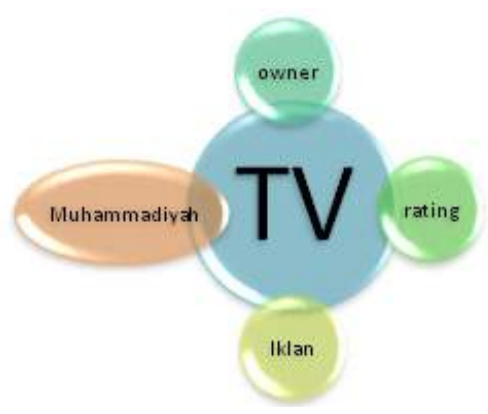

Gambar 2. Tiga hal yang mempengaruhi ADiTV yaitu owner, rating,,iklan dan Muhammadiyah.

Vincent Moscow mengatakan komodifikasi merupakan cara kapitalis mencapai kebutuhan kapital dengan merubah fungsi nilai menjadi fungsi tukar. Sehingga, kepentingan komersil dan kepentingan dakwah di ADiTV sangat kontras dalam penentuan tayangan.Tarikmenarik antara 2 kepentingan inilah yang menarik untuk diteliti. Sehingga permasalahan yang dapat dirumuskan adalah bagaimana kontestasi komodifikasi media dengan budaya organisasi Muhammadiyah.

Penelitian ini juga diharapkan dapat memberikan manfaat baik secara praktis maupun teoritis bagi ADiTV dan Muhammadiyah khususnya, dan khalayak pada umumnya. Penelitian ini akan menunjukkan hubungan antara tayangan, budaya organisasi dengan ekonomi politik di media. Penelitian ini akan melihat faktor- 
faktor penentu dalam sebuah konsep tayangan televisi.

Produk sangat terkait dengan proses komodifikasi. Sebuah tayangan televisi sebagai produk media televisi tentu tidak lepas dari proses produksi yang melibatkan para karyawan. Dalam hal ini karyawan menjadi komoditas yang dikomodifikasikan oleh pemilik modal. Ada 3 bentuk komoditas menurut Mosco. Pertama, komodifikasi konten, yakni media hanya berpatokan atau lebih mengutamakan nilai komersil dalam menyiarkan sebuah tayangan. Kedua, komodifikasi audiens, yakni audiens menjadi komoditas, karena tinggi rendahnya rating ditentukan dari jumlah audiens. Sedangkan rating digunakan sebagai senjata utama media untuk mendapatkan iklan. Makin banyak iklan maka makin banyak keuntungan komersil yang diperoleh media. Sehingga media melakukan berbagai cara untuk menyenangkan audiens. Ketiga, komodifikasi pekerja, dimana pekerja memegang peranan penting dalam proses produksi. Komodifikasi pekerja yakni dengan menanamkan pemikiran-pemikiran untuk tidak berorientasi pada upah atau gaji, tapi lebih kepada manfaat dan keuntungan ke depan yang bisa diperoleh, misalnya pengalaman, kebanggaan, loyalitas, dll.

Setelah komodifikasi konten, pemirsa, dan pekerja, Mosco mengembangkan 2 komodifikasi lagi yakni komodifikasi imanen dan komodifikasi yang diperluas. Komodifikasi imanen adalah ketika media menggunakan iklan untuk meningkatkan hasil penjualan produk-produknya. Dan rating menjadi penentu utama bagi pengiklan untuk membeli airtime. Sedangkan komodifikasi yang diperluas adalah ketika komodifikasi yang dilakukan oleh media dan pengguna media berdampak di masyarakat.

Bicara budaya organisasi adalah keyakinan dan nilai bersama yang memberikan makna bagi anggota sebuah institusi dan menjadikan keyakinan dan nilai tersebut sebagai aturan atau pedoman berperilaku di dalam organisasi (Achmad Sobirin, 2007: 131). Budaya organisasi melahirkan pola perilaku yang ditunjukkan oleh sekelompok orang sebagai akibat dari internalisasi keyakinan dan tata nilai yang telah diperoleh pada waktu-waktu sebelumnya (accomodationist school). Dua elemen dalam budaya organisasi yaitu elemen idealistik dan elemen behavioral. Elemen idealistik menjadi ideologi organisasi tidak mudah berubah meskipun organisasi selalu berubah dan beradaptasi dengan lingkungannya.

Organisasi memiliki lapisan-lapisan layaknya sebuah bawang (Rousseau dalam Sobirin, 2007).Lapisan ini menunjukkan elemen-elemen yang ada dalam budaya organisasi. Elemen ini berkaitan satu sama lainnya sebagaimana elemen idealistik dengan elemen behavioral.

Elemen yang ada dalam lapisan ini dari lapisan dalam keluar adalah sebagai berikut:

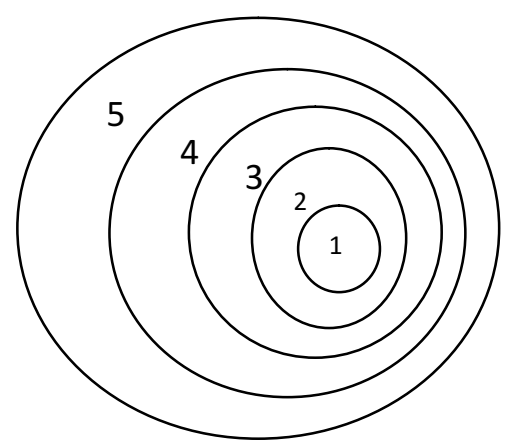

Gambar 3. Lapisan Elemen Budaya Organisasi

Sumber : Rousseau dalam Sobirin, Budaya Organisasi, 2007 hal: 157

Keterangan Gambar: 1. Asumsi Dasar; 2. Nilai; 3. Norma; 4. Perilaku; 5. Artefak

Asumsi dasar merupakan inti budaya organisasi.Budaya sebuah organisasi dalam banyak hal sangat dipengaruhi oleh asumsi 
yang berlaku dalam organisasi tersebut. Nilai-nilai organisasi adalah keyakinan yang dipegang teguh oleh seseorang atau sekelompok orang mengenai tindakan dan tujuan yang "seharusnya" dijadikan landasan atau identitas organisasi dalam menjalankan aktivitas, menetapkan tujuan atau memilih tindakan yang patut dijalankan dari alternatif pilihan yang ada. Artefak merupakan perwujudan dari asumsi dasar serta nilai yang dalam penelitian ini wujud dari artefak adalah perilaku komunikasi.

Industri media televisi merupakan salah satu industri padat modal. Diawal berdirinya ADiTV, Amin Rais sebagai Komisaris Utama ADiTV menyebutkan modal yang dipersiapkan pada waktu itu sebesar hampir 20 milyar rupiah (Sumber: http:/ / nasional.kompas.com/read/2008/0 4/12/19445550/muhammadiyah.dirikan.tv .lokal). Para pemilik modal tentu tidak akan lepas dari tujuannya untuk mencari keuntungan.

Peneliti membagi beberapa hal yang dapat mempengaruhi tayangan televisi secara umum dengan merujuk pada teori komodifikasi Vincent Mosco, yakni Pemilik modal, pengiklan, dan rating. Hubungan antara 3 hal yakni rating, pemilik modal, dan pengiklan yang secara umum menjadi pertimbangan untuk tayangan televisi. Rating dalam media TV secara ekstrim disebut "Tuhan" karena menentukan seberapa komersil sebuah tayangan.Pemilik modal yang paling menentukan tayangan.Dalam kondisi regular pemilik modal sejalan dengan rating dan pengiklan, tetapi, dalam kondisi tertentu misalnya ketika si pemilik modal memiliki kepentingan, maka pengiklan dapat digeser, bahkan program dapat dihilangkan dari tayangan regular.

ADiTV memiliki sesuatu hal yang cukup unik yang berbeda dengan stasiun televisi lokal lain, yakni selain 3 hal diatas, ADiTV juga dipengaruhi oleh ideologi
Muhammadiyah sebagai pendiri. Muhammadiyah memiliki misi dakwah amar ma'ruf nahi munkar. Industri media televisi lokal yang didirikan oleh Muhammadiyah dan menjadi senjata dakwah Muhammadiyah. Di awal lahirnya, yang menjadi tayangan perdana nya adalah siaran Muktamar se-abad Muhammadiyah, yakni merayakan usia gerakan Muhammadiyah yang sudah berumur 100 tahun. Sebagai perusahaan TV komersil ADiTV juga membutuhkan tayangan komersil guna mendatangkan iklan.Maka tidak menutup kemungkinan terjadi tarik menarik antara idealisme dakwah Muhammadiyah dengan kebutuhan tayangan TV kaitannya dengan komersialisasi program.

\section{Metode Penelitian}

Penelitian ini merupakan penelitian deskriptif kualitatif. Nelson menyatakan bahwa penelitian kualitatif merupakan bidang antar disiplin, lintas disiplin maupun kontra disiplin (Denzin, 1997: 5). Metode yang digunakan adalah studi kasus yakni penelitian dengan memamaparkan data penelitian baik lisan maupun tulisan dari informan/yang diamati (Bogdan dan Tylor, 1990). Penelitian ini bertujuan untuk memberikan gambaran tentang pengaruh ideologi Muhammadiyah terhadap tayangan program ADiTV. Melalui metode diskriptif akan mampu memaparkan fenomena secara rinci serta menghadirkan analisis yang lebih mendalam yang tidak mampu diungkap dengan metode kuantitatif. Penelitian ini merupakan penelitian dengan metode studi kasus, yang menjadi objek adalah TV swasta lokal di Yogyakarta, ADiTV.

Beberapa prosedur yang dilakukan peneliti adalah dengan melakukan observasi, wawancara mendalam, dan studi pustaka. Observasi dalam penelitian ini adalah dengan mengamati tayangan program dan iklan di ADiTV. Peneliti 
melakukan wawancara mendalam dengan manajemen ADiTV, Muhammadiyah, pengamat media dan tokoh masyarakat. Peneliti juga dapat mengembangkan pertanyaan sesuai dengan kebutuhan lapangan. Setelah itu Peneliti akan melihat dan mempelajari dokumen-dokumen seperti pendirian ADiTV, aturan, aturanaturan tertulis, kesepakatan-kesepakatan yang dikumpulkan peneliti.

Dalam penelitian ini analisis data yang d i g un a kan a d a la h m tod e deskriptif.Validitas data diperoleh melalui teknik triangulasi data. Data yang diperoleh dilapangan seperti hasil observasi lapangan, dokumen dan hasil wawancara mendalam, akan dianalisis dengan menggunakan referensi lain dan diinterpretasi oleh peneliti. Perolehan data disampaikan melalui paparan.

\section{Hasil Penelitian dan Pembahasan}

Dalam bab ini peneliti memulai bahasan dari laporan penelitian, penyajian data dan analisisnya. Peneliti menganalisis satu per satu hubungan antara ADiTVkebutuhan iklan, ADiTV-pemilik, ADiTVIdeologi Muhammadiyah.Sedangkan, hubungan ADiTV-rating dilewatkan karena belum ada ukuran yang tepat untuk stasiun televisi lokal. Penelitian ini dilakukan pada PT Arah Dunia Televisi (ADiTV). Observasi awal melalui pengamatan tayangan ADiTV untuk mengetahui bagaimana segmen dan konsep tayangannya. Peneliti mengamati program apa saja yang ditayangkan di ADiTV dan bagaimana konten program tersebut, begitu juga dengan iklan yang muncul.

Selain itu, peneliti melakukan wawancara mendalam terhadap 9 informan. Peneliti menentukan key informan yaitu dari jajaran direksi ADiTV. Informan keselanjutnya ditentukan menggunakan metode snow ball yaitu penunjukan dan pengembangan informasi oleh informan sebelumnya dengan menambahkan beberapa pertimbangan dari peneliti.Informan lainnya terdiri dari karyawan ADiTV, pejabat dan anggota aktif Muhammadiyah.Peneliti menanyakan beberapa hal terkait ADiTV dan muhammadiyah terhadap salah seorang pengamat media televisi.Salah seorang tokoh masyarakat Jogja yang turut berperan penting saat pendirian ADiTV juga berhasil diwawancarai oleh peneliti. Selain observasi dan wawancara mendalam peneliti juga melakukan studi dokumen terkait ADiTV. Peneliti mengumpulkan data seperti visi misi ADiV dari proposal pendirian, beberapa artikel di website, dan materi marketing. Peneliti juga mengumpulkan foto dan video tayangan program dan iklan dengan harapan akan menemukan data sekunder dalam penelitian ini.

\section{Hubungan ADiTV dengan Kebutuhan Iklan}

Peneliti melihat identitas media bagi pemirsanya tercermin dari tayangan apa yang disiarkan oleh media itu sendiri. ADiTV memiliki 14 program in-house atau yang diproduksi sendiri oleh ADiTV seperti yang tertera di website mereka. Jika dikelompokkan lagi maka ada 2 program dakwah yakni Mocopat Syafa'at dan Cahaya Rabbani, 2 program berita yakni Flash Jogja dan Lensa 44, 7 program hiburan yakni Galeri Halal, Mirip Sulap, Sinema, Ekspresikan Musikmu, Tembang Tembung, Wedang Ronde, dan Bintang Cilik, sisanya adalah program dialog kesehatan dan tokoh yakni Dokter Menyapa, Tamu Istimewa, Klinik Herbal dan Solusi Sehat. Selain itu sebetulnya masih ada 4 program lagi yang belum dicantumkan di website yakni: 1) Suara Editor, dialog yang membahas berbagai permasalahan di masyarakat dengan menghadirkan berbagai elemen masyarakat. 2) Adiklip, menampilkan video klip lagu-lagu Indonesia maupun luar negeri. 3) Campuss to Campuss, profil lembaga pendidikan seperti profil 
universitas. 5) Jendela Hati, program dakwah.

Beberapa panduan konten program di ADiTV diantaranya tidak boleh menayangkan program yang memecah belah umat, mengandung unsur SARA dan pornografi, termasuk iklan rokok, miras hukumnya haram tayang di ADiTV.

Peneliti mengamati programprogram tayangan di ADiTV. Sebagaimana panduan konten tayangan talent pria dan wanita berbusana sopan dan penyiar wanita menggunakan hijab yang sesuai dengan syariat Islam.

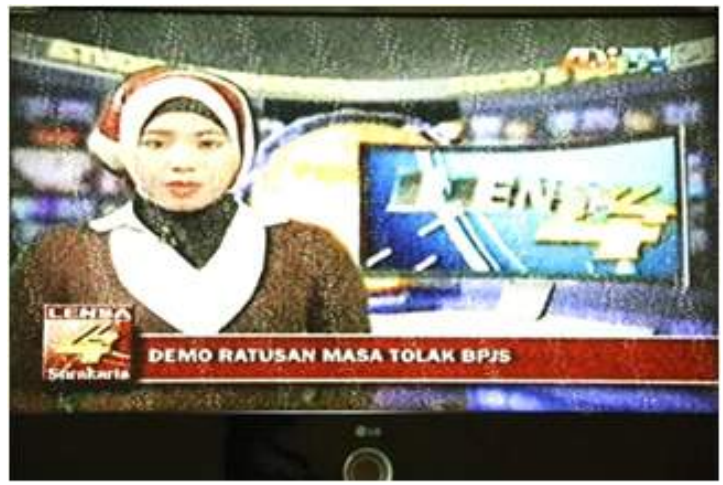

Gambar 4. Beberapa program dengan nuansa Islami

Nuansa Islami sangat kental ketika program dakwah Cahaya Robbani, Jendela Hati dan program tutorial hijab ditayangkan. Begitu juga dengan program unggulan Mocopat Syafaat meskipun menuai pro dan kontra.

Namun program Islami ini sangat kontras dengan program komersil seperti penayangan 2 iklan alat pelangsing dan celana jins legging. Pada iklan alat pelangsing yang menampilkan model wanita berbusana senam, atasan bikini sambil memamerkan tubuhnya. Kalimat dalam iklan tersebut juga mengajak para wanita untuk tampil seksi dan percaya diri di depan umum. Sedangkan, pada iklan celana jins legging model wanita menggunakan celana ketat dengan bagian perut yang terbuka.

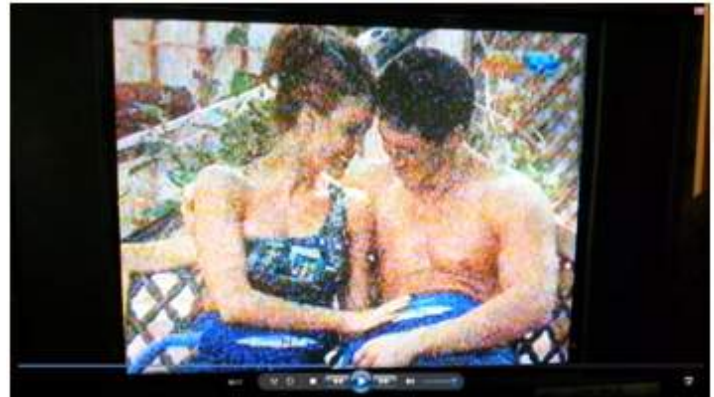

Gambar 5. Model pria dan wanita mengenakan busana renang dan berkesan intim.

Selain iklan alat pelangsing, ada juga iklan celana legging yang juga mendetailkan bentuk tubuh. Dalam iklan ini juga dikatakan "Le Jeans menunjukkan lekuk dan bentuk tubuh". Pada layar juga dituliskan "Desain Jins Seksi" dan model yang mengenakan celana jeans sobek-sobek dengan perut terbuka.

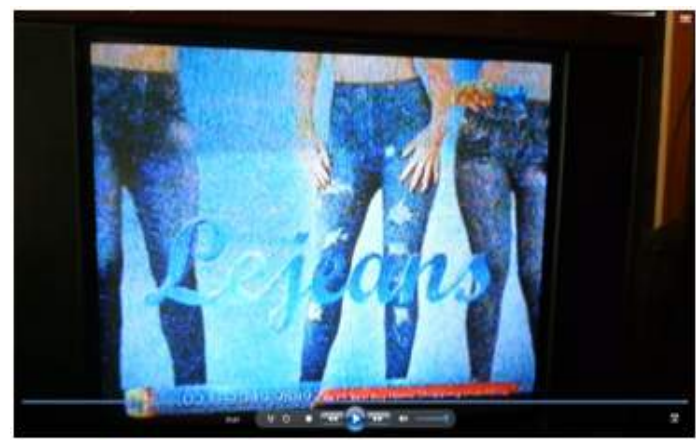

Gambar 6. Model wanita mengenakan celana ketat jins legging.

Pada program musik Adiklip yang menampilkan video klip artis nasional dan internasional menampilkan astis dengan busana terbuka.

Terkait soal program komersil, salah seorang direktur, Panji, mengaku bahwa ADiTV mengalami dilema soal penerapan panduan konten program. Selanjutnya, dicontohkan program kerjasama dengan pihak ketiga yang mana ADiTV tidak dapat merubah konten program. Sehingga, panduan konten program tadi hanya diberlakukan untuk program-program Inhouse. 
Pada kerangka teori penulis memaparkan teori Vincent Mosco yang menyebutkan salah satu komodifikasinya yakni komodifikasi konten atau isi media komunikasi. Konten media hanya berpatokan pada nilai komersil. Media membuat sebuah tayangan tanpa mempertimbangkan sisi manfaat dan dampak yang ditimbulkan di masyarakat.Komodifikasi konten ini terjadi di ADiTV ketika ada perberlakuan khusus untuk kepentingan komersilnya.

Kebutuhan komersil di media muncul karena media mengeluarkan biaya operasional rutin untuk produksi sebuah tayangan. Bagaimana pengiklan tertarik untuk mengiklankan produknya adalah bilamana program tayangan televisi tersebut menarik. Ukurannya bisa dari kualitas program, bisa juga dari rating. Masalahnya belum ada rating untuk stasiun televisi lokal. Karena itu marketing harus bekerja ekstra untuk meyakinkan program mereka adalah yang terbaik. Karena tidak ada rating maka penilaian klien akan sangat subjektif terhadap program di televisi yang ditawarkan.

Meskipun ada perlakuan khusus bahwa panduan konten program hanya untuk program-program in-house saja, ternyata bukan berarti marketing kemudian bebas untuk menentukan program maupun tayangan komersil di ADiTV. Peneliti mewawancarai bagian Marketing ADiTV, Nara, yang juga sempat "curhat" bahwa memang "gampang gampang susah" untuk menyesuaikan antara kebutuhan iklan dengan mentaati panduan konten program. Jika terlalu ketat aturan maka klien akan lari, sebaliknya jika terlalu terbuka dengan klien maka bisa dikomplain. Ia menambahkan selama ini menyerahkan sensor layak tayang sepenuhnya ke QC (Quality Control), seandainya pun sudah melewati QC bahkan rapat direksi masih menuai komplain pemirsa maka tayangan bisa di drop atau tidak ditayangkan kembali.
Namun disisi lain, contoh tayangan iklan yang bisa dikatakan tidak Islami juga bisa ditayangkan. Meskipun dalam wawancara, Nara selaku marketing menjelaskan iklan alat olahraga yang modelnya mengenakan pakaian senam dilarang tayang, iklan ditolak.Tapi pada prakteknya model wanita yang mengenakan bikini pada iklan alat pelangsing justru ditayangkan.

Menurut jajaran direksi ADiTV lainnya, Bakti, harus pintar pintar menjaga kepentingan antara kebutuhan iklan dan t a y a $\mathrm{ngan,} d$ e $\mathrm{ng}$ a $\mathrm{n}$ id e ologi Muhammadiyah.Ia mencontohkan soal komplain program Mocopat Syafa'at Cak Nun. Meskipun ia tidak berkenan menyebutkan siapa yang berkeberatan, ketika bercerita lebih lanjut akhirnya disebutkan pernah mengadakan forum dengan mengundang PWM, PDM, maka peneliti mengganggap bahwa itu adalah kalangan Muhammadiyah. Yang menjadi keberatan adalah ada yang berargumen tidak sesuai dengan Muhammadiyah, dan mengapa bukan orang Muhammadiyah, dan hal lainnya.Digambarkan diskusi dalam forum tersebut berlangsung cukup alot. Dan cara memberhentikan protes itu adalah dengan mengungkapkan sebuah fakta.

"Ya saya jawab saya, ADiTV itu pemiliknya Muhammdiyah tapi bukan TV Muhammadiyah, diem mereka semua." (Bakti, Direksi ADiTV, lokasi: ADiTV, 17 November 2014, 11.20 WIB).

Pernyataan ini selanjutnya akan dibahas di sub judul selanjutnya yakni hubungan ADiTV dengan pemilik. Peneliti kemudian ingin mengetahui jika ADiTV ini bukan TV Muhammadiyah lalu kenapa masih saja komplain datang dari kalangan Muhammadiyah. Bakti menjelaskan mungkin itu karena dulu ada tawaran untuk membeli saham ADiTV di awal berdirinya.

Dendi selaku pengamat media televisi ketika diwawancara peneliti menyampaikan bahwa tidak mungkin 
sebuah media televisi bersifat eksklusif sekalipun sebuah TV komunitas.Bicara aurat maka itu bersifat eksklusif.Padahal media televisi bersifat terbuka.

"Yang bukan Muhammadiyah dilarang nonton, kan nggak bisa. Aturan sebatas penyiar harus mengenakan hijab bisa saja diterapkan namun jika semua penyanyi wanita harus berhijab, Ya nanti kita nggak bisa dapet Krisdayanti dan lainlain" (Dendi, Pengamat Media, Lokasi: Kampus UAD, 28 Maret 2014,13.30 WIB).

\section{Hubungan ADiTV dengan Pemilik}

Dari banyak artikel yang peneliti telusuri peneliti secara online, hampir seluruhnya menyatakan ADiTV adalah TV Muhammadiyah. ADiTV diresmikan pada Muktamar 1 Abad Muhammadiyah. Dan ADiTV merupakan wujud dari keinginan yang sudah lama sekali di Muhammadiyah untuk memiliki sebuah stasiun televisi sebagai media dakwah. Mengutip artikel dari news.okezone.com yang memuat pernyataan Rektor Universitas Ahmad Dahlan, HM. Kasiyarno “...Mengingat ADiTV yang merupakan milik dari organisasi Muhammadiyah maka mengenai konten siaran hingga iklan nantinya tetap $\mathrm{me} \mathrm{mat} \mathrm{u} \mathrm{h} \mathrm{i} \mathrm{k} \mathrm{e} \mathrm{t}$ e $\mathrm{nt} \mathrm{u}$ a persyarikatan." (sumber: okezone.com). Sangat jelas dikatakan ADiTV adalah milik Muhammadiyah. Begitu juga dengan kutipan artikel di umum.kompasiana.com, “...Ketua Umum PP Muhammadiyah didampingi Sri Sultan HB X, Walikota Jogja selaku panitia penerima Muktamar dan Ketua PWM, diluncurkanlah televisi lokal milik Muhammadiyah ADiTV." (sumber: kompasiana.com).

Mewakili Majelis Tabligh, Pimpinan Pusat Muhammadiyah, Ahmad tidak bisa menjawab menjawab soal hubungan antara ADiTV dan Muhammadiyah juga sekaligus kepemilikannya, dan merekomendasikan salah seorang komisaris untuk diwawancarai peneliti lebih lanjut.

"Media dakwah yang digunakan
Muhammadiyah diantaranya adalah televisi.Saat ini Muhammadiyah memiliki TvMu atau Televisi Muhammadiyah. Sedangkan ADiTV, merupakan salah satu media tv yang digunakan untuk menyampaikan nilai-nilai Islam serta menyapa masyarakat muslim di Indonesia. Di ADiTV, Muhammadiyah turut serta mengisi acara-acara dakwah agama Islam." (Ahmad, Majelis Tabligh PP Muhammadiyah, via: email, 21 November 2014, 9.54 WIB).

Sebelumnya peneliti menyebutkan bahwa dalam wawancara dengan seorang direksi, Bakti, sempat menyebutkan ADiTV pemiliknya orang Muhammadiyah, tapi bukan milik Muhammdiyah. Jika kalangan Muhammadiyah masih banyak komplain soal program, itu karena dulu mereka pernah ditawari untuk membeli saham. Tawaran itu menyebar hingga ke tingkat ranting Muhammadiyah. Saham dijual sekitar seharga Rp 20.000,00. Selanjutnya peneliti melakukan roscekkepada salah seorang anggota aktif di salah satu Pimpinan Ranting Muhammadiyah, Soleh.Ia menjelaskan bahwa ADiTV dulu merupakan milik Muhammadiyah, sekarang ia tidak begitu jelas akan status ADiTV. Yang ia tau ADiTV kini sudah dimiliki oleh salah seorang tokoh Muhammadiyah. Sebelumnya, Soleh merasa yakin bahwa ADiTV adalah TV milik Muhammadiyah.

Sebuah postingan di hatta-rajasa.info tanggal 7 Desember 2012 memberitakan tentang Hatta Rajasa yang pada waktu itu Menko Perekonomian meresmikan Stasiun TV Islami ADiTV. "ADiTV diharapkan menjadi stasiun TV yang representatif, dan sebagai stasiun TV milik Muhammadiyah, ADiTV juga ingin menampilkan...". Artikel ini menunjukkan ADiTV adalah milik Muhammadiyah sekaligus diresmikan 2 kali, yang pertama adalah di Muktamar Muhammadiyah tahun 2010 lalu.

Peneliti menjabarkan tentang 
kepemilikan ADiTV sedemikian rupa karena peneliti menemukan ketidakjelasan status kepemilikan membuat kebingungan dalam hal konten tayangan. Sehingga ada ketidaksesuaian antara data dan fakta. Jika kepemilikan jelas akan menjadi lebih mudah bagi marketing untuk mendekati klien. Karena penilaian klien bersifat subjektif dengan tidak adanya system rating televisi di level lokal.

Jika ADiTV adalah TV milik Muhammadiyah, maka selayaknya visi misi ADiTV sejalan dengan visi misi Muhammadiyah. Tayangan ADiTV juga seharusnya mencerminkan dakwah Muhammadiyah. Jika demikian maka peneliti akan memperdalam bagaimana Muhammadiyah bertahan dengan konsep dakwahnya yang diprediksi akan berbenturan dengan kebutuhan komersil media televisi. Apakah anggotanya secara social memasukkan iklan mereka atau Muhammadiyah akan membuat aturan bahwa anggota wajib beriklan di televisi Muhammadiyah. Jika pemilik ADiTV adalah kalangan tokoh Muhammadiyah, maka setidaknya dalam menentukan kebijakan tayangan ada batasan yang memisahkan antara status pribadi dan status organisasi.Bagaimana pun sebagai pengusaha memiliki otoritas penuh terhadap perusahaannya. Jika demikian maka peneliti akan memperdalam bagaimana pemilik menggambarkan konsep Islami secara umum pada tayangan televisi, sekaligus secara pribadi menjaga identitas sebagai tokoh Muhammadiyah. Target pasar menjadi lebih jelas.Marketing bisa mendekati pemirsa non Muhammadiyah lebih mudah tanpa identitas Muhammadiyah.

Berdasarkan hasil wawancara peneliti dengan Hamid, salah seorang tokoh masyarakat yang juga terlibat aktif dalam pendirian ADiTV, ia menyatakan bahwa memang ADiTV sedang bermasalah soal kepemilikan. Ia menjabarkan ide awal munculnya ADiTV berasal dari Universitas Ahmad Dahlan (UAD). Karena berkaitan dengan kebutuhan modal maka UAD menggandeng Pimpinan Wilayah Muhammadiyah (PWM) Daerah Istimewa Yogyakarta. Setelah ADiTV berdiri dan berjalan, ADiTV membutuhkan dana operasional yang lebih. Saat itu Pimpinan Pusat (PP) Muhammadiyah belum menanggapi secara serius soal ini, lalu akhirnya disanggupi oleh Umar, salah seorang tokoh Muhammadiyah.Maka terjadilah perubahan kepemilikan yang mana awalnya ADiTV dimiliki oleh Universitas Ahmad Dahlan dan PWM DIY, sekarang sebagian besar saham, sekitar 55\% dimiliki oleh Umar. Dari hasil kesepakatan antara UAD, Umar, dan PWM, bahwa segala hal mengenai kebijakan soal ADiTV akan diputuskan dengan melibatkan ketiga unsur yakni UAD, Umar, dan PWM. Namun ketika kepemilikan baru berjalan, keputusan sepihak diambil oleh keluarga Umar tanpa melibatkan UAD dan PWM.

"Nah setelah proses ini, ini kemudian ada ketidakenakan antara muhammadiyah dengan Umar. Karena apa? Kemudian seolah-olah manajemen dari ADiTV itu ditekel oleh keluarganya Pak Umar semuanya. Nah ini menimbulkan keretakan sampai sekarang. Sehingga sekarang muhammadiyah lepas. Apalagi sudah ada tv digital itu. Nah ini menjadi Muhammadiyah kecewa dengan Pak Umar. ...Ya tidak jelas, karena apa, waktu itu saya dengan KPID, dengan UAD, sudah ada kesepakatan bahwa segala kebijakan yang diambil oleh ADiTV harus melibatkan 3 unsur, ya keluarganya Pak Umar, ya Muhammadiyah ya ADiTV sendiri gitu lo. La itu waktu itu harus diproses perubahan AD ART. Tapi sampai sekarang belum."(Hamid, Tokoh Masyarakat, lokasi: kediaman Hamid, 27 November 2014, 10.10 WIB).

Terlepas dari persoalan manajemen di ADiTV, peneliti beranggapan bahwa sangat 
penting untuk menegaskan siapakah pemilik modal dan bagaimana aturan main dalam organisasi pertelevisian itu sendiri, kaitannya dengan konten tayangan yang akan dihasilkan. Sebagaimana yang dijelaskan McQuail (dalam Ishadi, 2014:23), "Konten media selalu merefleksikan kepentingan pemilik modalnya. Dengan sekian bentuk kepemilikan media, implementasi kepentingan pemiliknya pun berbeda-beda."ADiTV secara hitungan modal jelas bahwa pemegang saham terbesar adalah Umar.Meskipun demikian pada pelaksanaannya, ADiTV tetap tidak dapat bebas untuk menunjukkan warna barunya atau setidaknya memberikan formula tentang batasan "seberapa" Muhammadiyah ADiTV sekarang.Sebaliknya meskipun secara hitungan saham baik UAD maupun PWM lebih kecil dibandingankan Umar, faktanya komplain tayangan yang datang dari warga Muhammadiyah tidak dapat diabaikan begitu saja oleh ADiTV.Soal 2 persepsi apakah ADiTV itu TV Muhammadiyah atau bukan, Hamid berpendapat itu hanya soal marketing saja, untuk merangkul warga Muhammadiyah.

"Ya memang keluarga Pak Umar akan mengatakan, supaya ada audiens yang berpihak harus melibatkan muhammadiyah betapa pun ruhnya jadi tidak muhammadiyah gitu lo. Itu strategi-strategi marketing aja kan gitu." (Hamid, Tokoh Masyarakat, lokasi: kediaman Hamid, 27 November 2014, 10.10 WIB).

\section{Hubungan ADiTV dengan Ideologi Muhammadiyah}

ADiTV sebagai sebuah stasiun TV memiliki visi misi sebagaimana tercantum di website resminya aditv.co.id. Visinya adalah "Menjadi TV lokal utama dan unggulan di Yogyakarta yang menayangkan program-program mendidik dan menarik bagi keluarga, khususnya Anak dan Ibu (A-D-I)". Sedangkan misinya adalah mensiarkan program TV dengan jiwa, nafas dan nuansa Islam dan kemuhammadiyahan, menjadi alternatif Utama tayangan televisi bagi masyarakat.Menjalankan unit usaha mandiri yang berorientasi manfaat dengan profesionalisme dan semangat perjuangan dakwah modern untuk mencerahkan seluruh masyarakat. Visi misi tersebut sedikit berbeda dengan visi misi yang disosialisasikan pada karyawan ADiTV. Visi ADiTV yang tercantum di poster yang ditempelkan di setiap ruangan ADiTV adalah "Menjadi Penyedia Konten Islami terbaik di Tanah Air (Best Islamic Content Provider) pada 2017". Sedangkan misinya adalah Pencerahan Bagi Semua, ADiTV ada untuk membawa pencerahan bagi semua.Menjadi Rahmatan lil alamin. Menyajikan tayangan televisi yang tidak hanya sekedar tontonan tapi juga menjadi tuntunan.

Menurut Direktur Panji, untuk menentukan tayangan rutin adalah melalui rapat produksi dan rapat direksi yang dilaksanakan setiap minggu. Ada 3 kategori program yakni Program Unggulan, Program Misi dan Program Komerial. Program Unggulan tidak mementingkan market, program idealisme para produser, dibiayai perusahaan. Program Misi merupakan inisiatif direksi, memastikan A D i T V t e ta p m e n u k u g kemuhammadiyahan dsb. Program Komersial adalah program berbayar yang diusulkan marketing melalui hasil riset pasar.

Ketiga program tersebut dipersentasekan secara merata dalam hal tayangan dan produksi, kurang lebih bobotnya $33 \%$ untuk masing-masing kelompok program. Tiga jenis program ini bisa saja berjalan seluruhnya, tetapi harus tetap satu dalam visi misi, satu dalam nilai besar yang dibawa perusahaan. Dari hasil pengamatan peneliti, tiga jenis program yang ditayangkan ADiTV belum satu pandangan. Hal ini terlihat dari 
ketidaksesuaian dalam penilaiannya sendiri. Disebutkan bahwa panduan konten program wajib menjadi acuan produksi program in-house, namun ada perlakuan berbeda pada program Tembang Tembung. Program ini kerap menerima protes soal busana host, yang mengenakan pakaian tradisional Jawa. Namun terdapat pengecualian atas nama seniman. Begitu juga dengan iklan yang dibawa marketing yang mempertontonkan model berbikini, memamerkan perut dan paha wanita secara fulgar yang jelas tidak Islami.Salah satu program unggulan yang mengedepankan idealisme produser dari sisi kreatif mungkin dapat diterima, namun dari sisi dakwah, busana yang ditampilkan tidak dapat diabaikan.

ADiTV memiliki sistem untuk penyaringan program tayangan yang layak atau tidak. Pengusulan program dimulai dari pembuatan dummy dan akan diputuskan di rapat direksi. Sedangkan untuk program yang sudah berjalan yang mengawal konten adalah QC (Quality Control) dengan melakukan rapat produksi setiap Hari Jumat.Dasar aturan yang ditetapkan adalah aturan KPID ditambah dengan aturan internal ADiTV. Namun apabila belum memiliki satu nilai yang disepakati bersama dan memayungi ketiga jenis program, maka sistem penyaringan ini sia-sia saja.

Tentang perubahan visi misi ADiTV, Panji menuturkan visi misi dulu lebih general sedangkan sekarang lebih dipersempit lagi untuk 2017 ADiTV menjadi penyedia konten Islami terbaik di Indonesia.Untuk pembukaan dan penutup siaran, setelah Lagu Indonesia Raya, dilanjutkan Mars Muhammadiyah karena masih merasa entitas Muhammadiyah, punya Muhammadiyah.Meskipun Pimpinan Pusat Muhammadiyah memiliki stasiun TV baru, TV Mu, Panji menguatkan bahwa ADiTV masih milik Muhammadiyah.
Peneliti menilai seharusnya tidak ada perbedaan visi misi.Meskipun dikatakan visi misi dulu dan sekarang, artinya sudah ada revisi. Visi misi yang terbaru yang sudah direvisi harus disosialkan kepada khalayak supaya tidak terjadi kesimpangsiuran yang berpengaruh pada konten program. Visi misi yang disosialisasi dengan dicantumkan di setiap ruangan ADiTV, yang diperuntukkan bagi seluruh karyawan, sama sekali tidak menyebutkan kata Muhammadiyah. Sedangkan visi misi yang tercantum dalam website resmi yang terbuka untuk umum menyebutkan kata "kemuhammadiyahan". Bisa jadi perbedaan target sosialisasi dan perbedaan materi yang disosialisasikan ini yang membuat tidak jelas apakah ini Muhammadiyah atau tidak.

Muhammadiyah sendiri menurut Ahmad, dari Majelis Tabligh, Pimpinan Pusat Muhammadiyah, sebagai gerakan dakwah memiliki konsep "amar ma'ruf nahi munkar" yakni menyeru untuk kebajikan dan mencegah keburukan. Dijelaskan lagi cara yang dilakukan dengan hikmah dan teladan berpikir serta teladan dalam berbuat. Sedangkan strateginya adalah fastabiq al-khairat atau berlomba-lomba dalam kebajikan.Pokok utamanya ada dalam kebajikan bukan dalam berlombalomba. Demikian juga dengan konsep mencegah kemunkaran dengan cara yang benar.

Menurut Panji, sekitar bulan FebruariMaret 2014, ADiTV mengumpulkan Pimpinan Muhammadiyah tingkat Wilayah dan Kabupaten dan karyawan ADiTV untuk meminta masukan sekaligus mengemukakan masalah yang dihadapi ADiTV pada prakteknya. Beberapa masalah yang pernah diprotes atau menjadi kontroversi adalah kenapa doa berbuka puasa menggunakan cara Nadhlatul Ulama. Dalam hal ini selaku salah seorang Direktur, Panji menjelaskan ketidaktahuannya dan juga kru produksi yang bukan dari kalangan 
Muhammadiyah sehingga pengetahuan tentang Muhammadiyahnya kurang.Lagilagi, jika televisi ini jelas bukan milik Muhammadiyah maka tidak perlu pusing dengan tayangan yang dianggap "tidak Muhammadiyah". Dan jika televisi ini adalah milik Muhammadiyah maka alasan tidak tau tentang kemuhammadiyahan atau karyawan bukan dari kalangan Muhammadiyah tidak dapat dijadikan alasan.

Dalam rapat komisaris juga pernah dibahas soal komplain tayangan Cak Nun, mengapa mengambil tokoh NU, rapat berlangsung a lot.

"Namun keputusannya karena ADiTV adalah TV publik maka setiap tayangan juga menyesuaikan dengan publik, bukan programnya yang dilarang tapi sensornya yang diperketat." (Panji, Direktur ADiTV, lokasi: Kampus UGM, 30 Juni 2014, 13.15 WIB).

Selain Mocopat Syafa'at, Tembang Tembung juga sering dikomplain soal busana host. Dan berkaitan dengan hal itu Panji menuturkan:

"Susah susah gampang, namanya juga seniman tapi biasanya tamu dari luar yang seperti itu." (Panji, Direktur ADiTV, lokasi: Kampus UGM, 30 Juni 2014, 13.15 WIB).

Dari berbagai hal yang tampak berbeda kepentingan, Muhammadiyah ternyata memiliki cara tersendiri untuk menyatukan kepentingan dakwah dan kepentingan komersil pada sebuah industri TV. Ada 3 (tiga) hal menurut Ahmad, yakni:

"Pertama, membuat program yang diisi oleh Majelis-majelis yang ada di lingkungan Muhammadiyah sesuai dengan visi, misi dan tujuannya kemudian disinergikan semuanya itu menjadi satu program yang men-display wajah dakwahMuhammadiyah dari berbagai perspektif.Kedua, amal usaha Muhammadiyah atau AUM (direncanakan) juga dirancang ikut mendanai manakala mereka beriklan.Ketiga, sumber-sumber yang halal dan tidak mengikat" (Ahmad, Majelis Tabligh PP Muhammadiyah, via: email, 21 November 2014, 9.54 WIB).

Jika Muhammadiyah memang dapat menjalankan ketiga hal itu maka menjadi bentuk komodifikasi yang diperluas yakni ketika Komodifikasi yang dilakukan oleh media dan pengguna media berdampak di masyarakat. Ketika masyarakat berperilaku meniru gaya hidup tokoh/artis di TV. Masyarakat menjadi lebih percaya terhadap sebuah produk tertentu, bahkan hingga mempengaruhi keputusan pribadi untuk kepentingan politik (Moscow: 2009). Tiga cara mensinergikan antara kepentingan iklan dengan kepentingan dakwah tersebut diatas akan memunculkan kelompok baru yakni TV semi komersil. Konsep mensinergikan antara dakwah dan komersil juga disampaikan oleh Hamid.

"Mungkin semi bisnis semi dakwahlah tetapi bisnisnya yang tidak menyalahi akidah dan moral Islam.Kalau Muhammadiyah itu bisa bicara bisnis secara baik, sebenarnya potensi Muhammadiyah it u besar. Berapa pengusaha Muhammadiyah yang ada, berapa amal usah yang ada.Itu lumayan gitu lo. Bisa agak menutup gitu lo karena kalau toh misalnya harus menganggarkan 100\% kemudian 5050, dari Muhammadiayah 50 dari 50 itu sebenernya masih bisa kok." (Hamid, tokoh masyarakat, lokasi: kediaman Hamid, 27 November 2014, 10.10 WIB). Ishadi SK dalam buku "Media dan Kekuasaan" menggambarkan 3 sistem televisi dan pertanggungjawabannya.

Tabel 1.Tiga Sistem Televisi dan

Pertanggungjawabannya.

\begin{tabular}{|c|c|c|c|}
\hline & $\begin{array}{l}\text { TELEVISI } \\
\text { PEM ERINTAH }\end{array}$ & $\begin{array}{l}\text { TELEV IS I } \\
\text { SWASTA }\end{array}$ & TELEVISI PUBLIK \\
\hline Investasi & Pemerintah & Swasta & Pemerintah/Negara \\
\hline $\begin{array}{l}\text { Biaya } \\
\text { Operasional }\end{array}$ & APBN/APBD & $\begin{array}{l}\text { Iklan atau sponsor } \\
\text { program }\end{array}$ & $\begin{array}{l}\text { Iuran } \\
\text { terbatas }\end{array}$ \\
\hline $\begin{array}{l}\text { Bertanggung } \\
\text { Jawab kepada }\end{array}$ & $\begin{array}{l}\text { Pemerintah } \\
\text { (Departemen en } \\
\text { Penerangan, } \\
\text { Lembaga yang } \\
\begin{array}{l}\text { ditunjuk k oleh } \\
\text { Pemerintah) }\end{array}\end{array}$ & Pemegang Saham & Parlemen \\
\hline $\begin{array}{l}\text { Mater ri/Substans } \\
\mathrm{i}\end{array}$ & $\begin{array}{l}\text { Propaganda } \\
\text { pemerintah }\end{array}$ & $\begin{array}{lr}\text { Berorientasi } & \text { pada } \\
\text { pasar, market driven } \\
\text { oriented. } \\
\text { culture }\end{array}$ & $\begin{array}{l}\text { Kepentingan } \\
\text { high culture }\end{array}$ \\
\hline Pengelolaan & $\begin{array}{l}\text { Birokrasi } \\
\text { pemerintah }\end{array}$ & $\begin{array}{l}\text { Profesional/Competit } \\
\text { ive }\end{array}$ & $\begin{array}{l}\text { Profesional/Competitiv } \\
e\end{array}$ \\
\hline
\end{tabular}


Peneliti juga mengkonsultasikan secara langsung soal tarik menarik kepentingan dalam media televisi kepada Dendi, pengamat media televisi.

"Tidak ada televisi yang berdasarkan pada ideologi.Ideologi kita Pancasila." (Dendi, Pengamat Media, Lokasi: Kampus UAD, 28 Maret 2014, 13.30 WIB).

Ketika peneliti menanyakan soal ideologi dari kacamata subjek sebagai warga Negara Indonesia atau warga Muhammadiyah, Dendi beranggapan dikotomi seperti itu harus dibuang.

"Identitas sebuah Televisi Muhammadiyah boleh saja, hanya porsinya yang harus diatur.Ketika seorang presenter di TV itu adalah warga Muhammadiyah maka dia wajib mengenakan jilbab." (Dendi, Pengamat Media, Lokasi: Kampus UAD, 28 Maret 2014, 13.30 WIB).

\section{Simpulan}

Identitas sebuah media televisi sangat penting untuk menentukan standar tayangan dan perkembangan perusahaan dalam jangka panjang. Jika identitas televisi bias atau tidak jelas maka bisa diprediksi media tersebut akan jalan di tempat, walaupun berkembang maka perkembangannya pun tidak akan signifikan. Ibarat manusia, dia memiliki keinginan kuat, kemampuan ada, tapi tidak tahu arah akan kemana, untuk berbuat apa. Ada sesuatu yang membuat Muhammadiyah tidak dapat lepas begitu saja dari ADiTV, begitu juga dengan ADiTV yang tidak bisa begitu saja mengacuhkan Muhammadiyah. Sehingga ketika ada pertanyaan "Ini TV Muhammadiyah bukan?" atau "Seberapa Muhammadiyah ADiTV?" hingga laporan ini dibuat belum terjawab dengan jelas. Karena pada dasarnya ADiTV belum dapat mengenal identitasnya sendiri. Peneliti juga melihat ada misskomunikasi dan missinformasi baik antara Organisasi Muhammadiyah dengan ADiTV, maupun dengan person anggota
Muhammadiyah hingga ke karyawan ADiTV. Sehingga masing-masing pihak memiliki persepsi penilaian masing-masing soal ADiTV.

Ketidakjelasan status ADiTV apakah TV Muhammadiyah atau bukan dapat merugikan bagi kedua belah pihak baik ADiTV sendiri maupun Muhammadiyah. Kerugian ADiTV diantaranya adalah seluruh jajaran ADiTV tidak dapat bebas menentukan kebijakan terutama yang bersinggungan dengan nilai dakwah Muhammadiyah. Meskipun terdapat aturan main secara formal pada prakteknya yang berjalan adalah konsep "gampanggampang susah" dalam rangka menyesuikan kebutuhan komersil dan dakwah. Selain itu hubungan yang kurang harmonis dengan Muhammadiyah dapat menimbulkan isu "menggunakan" Muhammadiyah untuk kepentingan komersil. Di pihak lain konsep dakwah Muhammadiyah amar ma'ruf nahi munkar menjadi tidak murni dan nilai-nilai dakwahnya menjadi dipertanyakan akibat tayangan ADiTV yang dianggap tidak sesuai.

Karena tarik menarik antar kepentingan di media televisi itu selalu ada, ditambah dengan identitas Muhammadiyahnya yang cukup kuat untuk wilayah Daerah Istimewa Yogyakarta, maka ADiTV harus menentukan satu titik pedoman, kesamaan arah pandang, yang bisa dijadikan kiblat dalam pengambilan keputusan, sehingga dapat lebih menguatkan tayangan yang akan berdampak pada branding ADiTV. Bisa dimulai dengan menyamakan visi misi. Visi misi ini hendaknya dapat disosialisasikan di internal maupun eksternal ADiTV. Status juga harus jelas apakah ini TV Muhammadiyah atau TV Islami tanpa embel-embel Muhammadiyah dan bagaimana perlakuannya yang cukup menarik untuk diteliti selanjutnya adalah bagaimana persepsi masyarakat Jogja 
terhadap ADiTV. Dari sini dapat terlihat seberapa efektif atau seberapa sukses komunikasi yang dibangun ADiTV di masyarakat.

\section{Daftar Pustaka}

Denzin, K Norman. (1997). Handbooks of Qualitative Reseach. California,USA: Sage Publication

Ishadi SK. (2014). Media dan Kekuasaan. Jakarta: Kompas.

Jensen B Klaus \& Jankowski, W Nicholas. (1992). A Handbook of Qualitative Methodologies for Mass Communication Research. New York: Routledge.

Muhammad Arnis. (2002). Komunikasi Organisasi. Jakarta: BumiAksara.

PT Arah Dunia Televisi. (2008). Studi Kelayakan Lembaga Penyiaran Swasta ADiTV.

Tubbs Stewart dan Moss Sylvia. (1996). Human Communication. Bandung: Rosdakarya.

Turner, West. (2010). Introduction Communication Theory Fourth Edition. New York: McGraw Hill.

\section{Website:}

smkmuh3solo.net. Tersedia dari: http:/ / smkmuh3solo.net/2013/05/1 4/muhammadiyah-jogja-dirikantelevisi-aditv.html, akses terakhir 24 November 2014, jam 2.59 WIB.

Hatta-rajasa.info. Tersedia dari: $\mathrm{h} t \mathrm{t} p: / / \mathrm{h}$ a $\mathrm{t} t \mathrm{a}$ rajasa.info/read/1112/hattaresmikan-tv-muhammadiyah, akses terakhir 24 November 2014, jam 3.00 WIB.
Jogjanews.com. Tersedia dari: http://jogjanews.com/muhammadiy ah-launching-adi-tv, akses terakhir 24 November 2014, jam 3.01 WIB.

Kompas.com. Tersedia dari: http:/ / nasional.kompas.com/read/2 008/04/12/19445550/muhammadiya h.dirikan.tv.lokal, akses terakhir 24 November 2014, jam 3.01 WIB.

Kapanlagi.com Tersedia dari: http://www.kapanlagi.com/showbi $\mathrm{z} /$ televisi/amien-rais-akan-dirikanstasiun-tv-di-yo gyakartadvf3src.html, akses terakhir 24 November.

Muhammadiyah-kaltim.blogspot.com. Tersedia dari: http://muhammadiyah kaltim.blogspot.com/2008/05/tvmuhammadiyah-diy-aditv-jalaniedp.html, akses terakhir 24 November 2014, jam 3.02 WIB.

Kompasiana.com. Tersedia dari: http://umum.kompasiana.com/2009 /07/25/muhammadiyah-punya-tvsiapa-menyusul-9146.html, akses terakhir 24 November 2014, jam 3.03 WIB.

Muhammadiyahdiy.or.id. Tersedia dari: http:// muhammadiyahdiy.or.id/opi ni/baca/173/aditv_berikan_tontona n_dan_tuntunan, akses terakhir 24 November 2014, jam 3.04 WIB. 